\title{
Temporal abundance patterns of the red tide dinoflagellate Noctiluca scintillans along the southeast coast of Australia
}

\author{
Jocelyn Dela-Cruz ${ }^{1,2, *}$, Penelope Ajani ${ }^{3}$, Randall Lee ${ }^{3}$, Tim Pritchard ${ }^{3}$, Iain Suthers ${ }^{1}$ \\ ${ }^{1}$ School of Biological Earth and Environmental Science, University of New South Wales, Sydney 2052, New South Wales, Australia \\ ${ }^{2}$ Environmental Science Section, and ${ }^{3}$ Water Science Section, Environment Protection Authority, PO Box A290, \\ Sydney South 1232, New South Wales, Australia
}

\begin{abstract}
Noctiluca scintillans was seasonally abundant during the austral spring and summer with typical values of 16 cells l$^{-1}$, but depleted in autumn and winter, with values of $<1$ cell $^{-1}$. Peaks in abundance of up to 79 cells $1^{-1}$ were observed, at the same time or subsequent to diatom blooms which were caused by episodic uplifting events during the spring and summer. The diatom blooms were dominated by the small centric diatom Thalassiosira partheneia, which was also the dominant food item found within the Noctiluca cells. A high proportion $(>80 \%)$ of Noctiluca cells contained food particles in their vacuoles during the diatom blooms, suggesting that the increase in abundance of Noctiluca was most likely stimulated by food availability. Pulses of small-sized Noctiluca cells during the diatoms blooms were indicative of this population growth. The $\delta^{15} \mathrm{~N}$ isotopic similarity of the red tide cells collected from spatially and temporally distant water masses suggests that the prey of Noctiluca were derived from a single nutrient source, most likely uplifted slope water. This study shows that the predominant underlying mechanism regulating population growth of Noctiluca along the southeast coast of Australia is the uplifting of nutrient-rich slope water. The uplifting events stimulate phytoplankton blooms which in turn stimulate Noctiluca blooms.
\end{abstract}

KEY WORDS: Red tides $\cdot$ Noctiluca $\cdot$ Dinoflagellates $\cdot$ Uplifting $\cdot$ Slope water $\cdot$ Thalassiosira

\section{INTRODUCTION}

One of the best known red tide forming organisms in coastal waters around the world is Noctiluca scintillans, a large heterotrophic dinoflagellate (Elbrachter \& Qi 1998). Noctiluca is considered to be a protistan species harmful to fish since it has been responsible for large-scale deaths of caged fish (Smayda 1997, Naqvi et al. 1998). Noctiluca produces a simple ichthyotoxin $\left(\mathrm{NH}_{3}\right)$ and causes $\mathrm{O}_{2}$ depletion of surface waters during bloom decay (Smayda 1997). Noctiluca blooms are formed by an accumulation of the buoyant cells on the sea surface and may be transported by prevailing winds, tides and oceanic currents (Le Fevre \& Grall

*E-mail: delacruz@epa.nsw.gov.au
1970, Schaumann et al. 1988, Huang \& Qi 1997). Causes of population growth of Noctiluca are difficult to determine due to these advective processes. Longterm field studies on the population ecology of NoCtiluca in the North Sea (Uhlig \& Sahling 1990) and South China Sea (Huang \& Qi 1997) show that water temperature, salinity, phytoplankton biomass and/or day length are the main environmental determinants for growth of Noctiluca. Results from shorter-term field studies and from numerous laboratory studies (Elbrachter \& Qi 1998) are consistent with those reported in the North Sea and South China Sea. However, the exact relationships between Noctiluca and various environmental determinants vary between the regions. For instance, a positive correlation between Noctiluca abundance and phytoplankton biomass has been established in southern Benguela (Painting et al. 
1993) but a negative correlation was found in the South China Sea (Huang \& Qi 1997). The mechanisms controlling the spatial and temporal fluctuations in the various environmental determinants also differ between regions.

Noctiluca scintillans is currently the most common red tide-forming species along the south-east coast of Australia (Ajani et al. 2001a). The observed frequency of occurrence of Noctiluca was sporadic up until the 1980s. Since then, Noctiluca red tides appear to have increased in frequency and intensity, with the majority of blooms recorded in the 1990s (Hallegraeff 1993, 1995, Ajani et al. 2001a), soon after the commissioning of 3 deepwater ocean sewage outfalls off Sydney, Australia's largest coastal city. There is currently very little known about the hydrological and ecological conditions causing population growth of Noctiluca off Sydney, where most of the red tides have been reported. Annually recurrent algal blooms, predominantly caused by diatoms, have been documented in Sydney's coastal waters since 1959 (Humphrey 1963). Subse-

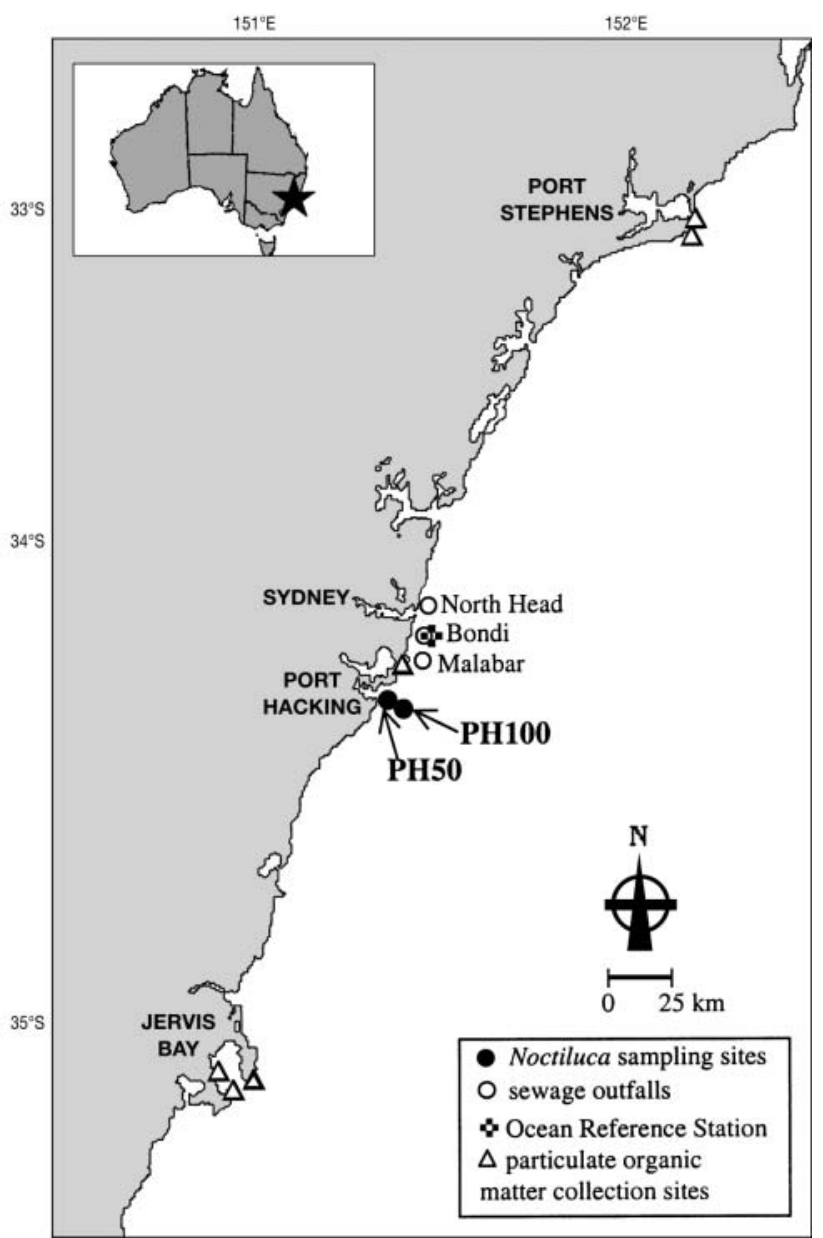

Fig. 1. Location of the main study areas along the southeast of New South Wales, Australia; Port Stephens, Sydney and Jervis Bay quent studies have established a predictable sequence of algal blooms along the south-east coast of Australia (Jeffrey \& Carpenter 1974, Hallegraeff \& Reid 1986, Hallegraeff \& Jeffrey 1993). In all of these studies Noctiluca was only mentioned anecdotally since it was considered to be a minor component of the plankton community.

The purpose of the present study was to identify and quantify the biological, chemical and physical variables regulating the temporal abundance patterns of Noctiluca scintillans off Sydney. The study was conducted at 2 long-term monitoring stations off Sydney, where previous plankton studies had taken place. The sampling protocol and methods used in the study of Hallegraeff \& Reid (1986), conducted almost 20 yr prior to the present study, were replicated in an attempt to determine whether there had been a real increase in the abundance of Noctiluca over time. Stable isotope analyses of bloom material were also conducted to identify the nutrient source(s) for the prey of Noctiluca.

\section{MATERIALS AND METHODS}

Collection of samples. Samples were collected approximately weekly (every 4 to $10 \mathrm{~d}$ ) from 2 coastal stations off Port Hacking near Sydney, New South Wales (NSW), Australia (Fig. 1) between March 1997 and the end of March 1998. The stations were sampled regularly by the Commonwealth Scientific and Industrial Research Organisation (CSIRO) prior to this study (Lee et al. 2001) and are known as the Port Hacking $50 \mathrm{~m}$ station (PH50) and the Port Hacking $100 \mathrm{~m}$ station (PH100). PH50 is located approximately $2 \mathrm{~km}$ off shore of the Royal National Park at $34^{\circ} 05.65^{\prime} \mathrm{S}$, $151^{\circ} 11.63^{\prime} \mathrm{E}$, and $\mathrm{PH} 100$ at approximately $6 \mathrm{~km}$ offshore at $34^{\circ} 06.98^{\prime} \mathrm{S}, 151^{\circ} 13.14^{\prime} \mathrm{E}$ (Fig. 1).

Plankton nets were used to collect Noctiluca scintillans rather than bottle sampling (Uhlig \& Sahling 1990), as up to $50 \%$ of the sampling dates (austral autumn and winter months) coincided with periods of low abundance (<1 cell ${ }^{-1}$; Murray \& Suthers 1999). Noctiluca was collected by vertical casts of $0.2 \mathrm{~m}$ diameter, $100 \mu \mathrm{m}$ mesh plankton net to a depth of $50 \mathrm{~m}$ or less depending on the depth of the water column. The net was vertically deployed and hauled to the surface, sampling on the way down and up to filter 2.5 to $3.1 \mathrm{~m}^{3}$ of seawater. Only 1 vertical haul was taken at each station during the majority of the sampling dates. Variability in the abundance of Noctiluca at spatial scales of $<100 \mathrm{~m}$ at each station was assumed to be small compared to variability between the 2 stations and variability over time (Murray \& Suthers 1999). This assumption was assessed by conducting 3 replicate vertical hauls at the PH50 and PH100 stations in Sep- 
tember, October, November and December. The mean coefficient of variation in zooplankton abundance (including Noctiluca) among replicate hauls was $14.2 \pm$ $2.2 \%$, the mean coefficient of variation in zooplankton abundance between stations was $34.8 \pm 9.9 \%$, and the mean coefficient of variation in zooplankton abundance over time was $45.5 \%$, indicating that the assumption was valid.

All samples were collected between 09:30 and 12:00 h. Samples were preserved with $5 \%$ formalin (final concentration), until analysis in the laboratory. Phytoplankton samples, integrated over the top $100 \mathrm{~m}$ of the water column, were collected at Stn PH100 concurrently with the vertical casts using a $35 \mu \mathrm{m}$ freefall plankton net identical to that used by Hallegraeff \& Reid (1986). The samples were preserved with $3 \%$ glutaraldehyde (final concentration) and stored in the refrigerator until analysis. Phytoplankton identification and enumeration were conducted by the NSW Environment Protection Authority (EPA) Water Science Section (Ajani et al. 2001b).

Measures of chlorophyll $a$ and physical and chemical variables. Water samples used for analyses of chlorophyll a (chl a) and nutrients (oxidised nitrogen [nitrate + nitrite], $\mathrm{NO}_{2}^{-}+\mathrm{NO}_{3}^{-}$; ammonia, $\mathrm{NH}_{3}$ i dissolved reactive phosphorus, FRP; dissolved reactive silicate, $\mathrm{Si}$ ) were collected throughout the water column using Niskin bottles. The bottles were positioned at depths of $0,10,20,30,40,50 \mathrm{~m}$ at the PH50 station and at depths of $0,10,25,50,75,100 \mathrm{~m}$ at the PH100 station. Two 1 of each sample of seawater were filtered through a $0.2 \mu \mathrm{m}$ glass fibre filter under low vacuum within $6 \mathrm{~h}$ of collection for chl a analysis. The filter paper was folded, blotted dry, wrapped in aluminium foil and stored at $-20^{\circ} \mathrm{C}$ until analysis. The chl a content of the samples was determined using the American Public Health Association (APHA) Method 10200. The Practical Quantitation Limit of this method was $1 \mathrm{~g} \mathrm{I} \mathrm{l}^{-1}$. Water collected for analysis of nutrients was filtered through a $0.45 \mu \mathrm{m}$ disposable syringe filter within $6 \mathrm{~h}$ of collection and frozen at $-20^{\circ} \mathrm{C}$ for $\mathrm{NO}_{2}{ }^{-}+$ $\mathrm{NO}_{3}{ }^{-}, \mathrm{NH}_{3}, \mathrm{FRP}$ analyses, or stored at room temperature in the dark for Si analyses. The nutrient content of the samples was determined using the APHA Method 4500 modified for $\mathrm{NO}_{2}{ }^{-}+\mathrm{NO}_{3}{ }^{-}, \mathrm{NH}_{3}, \mathrm{FRP}$ and $\mathrm{Si}$. The Practical Quantitation Limits were 0.07, 0.14, 0.03 and $0.18 \mu \mathrm{M}$, respectively.

Water temperature and conductivity (salinity) were measured in situ every meter to a depth of $50 \mathrm{~m}$ or $100 \mathrm{~m}$ using a SEABIRD SBE25 conductivity, temperature and depth (CTD) unit. Additional water temperature, current and wind speed data were collected from the Ocean Reference Station (ORS) situated at $33^{\circ} 54^{\prime} \mathrm{S}, 151^{\circ} 18^{\prime} \mathrm{E}$ on the $65 \mathrm{~m}$ isobath, approximately $25 \mathrm{~km}$ north of the study area in Sydney (Fig. 1). The
ORS is a permanently moored facility that records wind velocity $5 \mathrm{~m}$ above the sea surface, has current meters positioned at depths of $17 \mathrm{~m}$ and $50 \mathrm{~m}$, and has 16 temperature loggers positioned at $3 \mathrm{~m}$ depth intervals between 0.6 and $52.5 \mathrm{~m}$ depth. The ORS is maintained and calibrated by Manly Hydraulics Laboratory for Australian Water Technology who kindly supplied the data.

Analyses and enumeration of samples. Vertical haul samples arising from the $100 \mu \mathrm{m}$ mesh net were analysed in a manner similar to that described by Murray \& Suthers (1999). Preserved samples were gently sieved and rinsed with seawater through a $90 \mu \mathrm{m}$ mesh sieve and concentrated to 0.11 . The abundance of Noctiluca scintillans and abundance of zooplankton were determined from 2 replicate subsamples of the 0.11 concentrate using a dissecting microscope. The condition of Noctiluca was characterised by the diameter, reproductive and nutritional status of the cells. Cell diameters of the first 60 cells encountered in the sample were calculated from the area of the cells, measured using the public domain NIH Image program developed at the US National Institutes of Health and retrievable from the Internet at: http:// rsb.info.nih.gov/nih-image. The numbers of asexually dividing and swarmer-forming cells were determined from 500 cells in each sample (Uhlig \& Sahling 1995). Nutritional status of Noctiluca was determined from the first 30 cells encountered in each of the 2 replicate subsamples. The cells were classed as being 'empty' if they had no food particles or 'fed' if they contained food particles (Uhlig \& Sahling 1995). The cell contents were determined for the first 20 fed cells encountered in samples that had relatively high numbers of Noctiluca. Fed cells were isolated and burst before the cell contents were examined at a maximum magnification of $\times 400$ using a compound microscope.

Stable isotope composition of red tides. Twenty-one red tides of Noctiluca scintillans were reported by the general and scientific public to the NSW EPA during the period of the study. These red tides were all sighted off coastal waters between Port Stephens and Jervis Bay. Six of these red tides were sampled to determine diameter, nutritional status and stable isotope signatures of nitrogen and carbon of the cells ( $\mathrm{n}=$ 4 samples per red tide). For reference, the stable isotope signatures of red tides were compared to the stable isotope signature of primary treated effluent collected from Sydney's 3 main sewage treatment plants (North Head, Bondi and Malabar) and to the signature of particulate organic matter (POM) sampled from coastal waters off Port Stephens, Sydney and Jervis Bay (Fig. 1). Red tide samples (whole and lysed cells) were initially filtered through a $90 \mu \mathrm{m}$ mesh sieve to remove excess seawater. POM was obtained by filter- 
ing 6 to 81 of seawater through a $150 \mu \mathrm{m}$ mesh sieve to remove zooplankton and then through a $0.2 \mu \mathrm{m}$ glass fibre filter. Similarly, the effluent was filtered through glass fibre filters to retain particulates, and the $\delta^{15} \mathrm{~N}$ and $\delta^{13} \mathrm{C}$ of both the particulate and filtrate fractions of the effluent samples were determined. Red tide, effluent and POM samples were freeze-dried, and dry weights of 1 to $2 \mathrm{~g}$ were sent to CSIRO Land and Water, South Australia, where the samples were analysed by Automated Nitrogen Carbon Analysis Mass Spectrophotometry. The samples were combusted and the reaction products were separated by gas chromatography to give pulses of pure nitrogen and carbon dioxide for analyses of total $\mathrm{N}$, total $\mathrm{C},{ }^{15} \mathrm{~N}$ and ${ }^{13} \mathrm{C}$ by the mass spectrophotometer (20-20, Europa Scientific).

Data analyses. When mean values are reported, the standard error of the mean (i.e. mean $\pm \mathrm{SE}$ ) is provided unless otherwise indicated. Variability in abundance, percent dominance, cell diameter and nutritional status in the weekly samples of Noctiluca scintillans was assessed by non-metric multi-dimensional scaling (MDS; Clarke 1993) and hierarchical agglomerative clustering using PRIMER software developed by the Plymouth Marine Laboratory. Similarity matrices of the standardised data were generated using the BrayCurtis coefficient calculated between samples. MDS plots were generated from an iterative technique used to find the best display of the 4 variables in 2 dimensions. Stress values indicated how well the multivariate data were represented in 2 dimensions (low stress is <0.2; Clarke 1993).

Table 1. Rotated (varimax) component loadings generated from a PCA of physical, chemical and chl a data at Stns PH100 and PH50 (data for stations pooled). Subscripts B and S denote bottom and surface layers of the water column respectively. Variables with high loadings (e.g. >0.7) for a particular $\mathrm{PC}$ factor are highlighted in bold font

\begin{tabular}{|c|c|c|c|c|}
\hline Variable & Factor 1 & Factor 2 & Factor 3 & Factor 4 \\
\hline $\mathrm{T}_{\mathrm{B}}$ & -0.89 & -0.16 & 0.07 & 0.06 \\
\hline $\mathrm{T}_{\mathrm{S}}$ & -0.03 & -0.70 & 0.14 & 0.13 \\
\hline $\mathrm{S}_{\mathrm{B}}$ & -0.92 & -0.17 & -0.09 & 0.02 \\
\hline $\mathrm{S}_{\mathrm{S}}$ & -0.37 & -0.42 & -0.41 & 0.40 \\
\hline $\mathrm{FRP}_{\mathrm{B}}$ & 0.95 & 0.15 & 0.06 & 0.03 \\
\hline $\mathrm{FRP}_{\mathrm{S}}$ & 0.30 & 0.85 & 0.01 & -0.08 \\
\hline $\mathrm{NO}_{2}^{-}+\mathrm{NO}_{3}^{-}{ }_{\mathrm{B}}^{-}$ & 0.96 & 0.11 & 0.04 & 0.02 \\
\hline $\mathrm{NO}_{2}^{-}+\mathrm{NO}_{3}^{-}{ }^{-}$ & 0.36 & 0.82 & -0.00 & -0.05 \\
\hline $\mathrm{NH}_{3_{\mathrm{B}}}$ & -0.07 & -0.09 & 0.87 & -0.08 \\
\hline $\mathrm{NH}_{3 \mathrm{~S}}$ & 0.16 & 0.05 & 0.83 & 0.06 \\
\hline $\mathrm{Si}_{\mathrm{B}}{ }^{-\mathrm{S}}$ & 0.90 & 0.14 & 0.11 & 0.21 \\
\hline $\mathrm{Si}_{\mathrm{S}}$ & -0.09 & 0.76 & 0.23 & 0.28 \\
\hline $\mathrm{Chl} a_{\mathrm{B}}$ & -0.40 & -0.08 & 0.10 & -0.76 \\
\hline $\mathrm{Chl} a_{\mathrm{S}}$ & 0.28 & 0.54 & -0.15 & -0.58 \\
\hline $\begin{array}{l}\% \text { of total variance } \\
\text { accounted for }\end{array}$ & 34.96 & 21.88 & 12.38 & 8.81 \\
\hline
\end{tabular}

The physical (temperature, salinity), chemical $\left(\mathrm{NO}_{2}^{-}\right.$ $+\mathrm{NO}_{3}{ }^{-}, \mathrm{FRP}, \mathrm{NH}_{3}, \mathrm{Si}$ ) and chl a data for surface (subscript S) and bottom (subscript B) water layers (50 m or $100 \mathrm{~m}$ depending on the depth of the water column at each station) were ordinated by Principal Component Analysis (PCA) using SYSTAT ${ }^{\circledR}$ 7.0.1 for Windows. Surface values for each variable were calculated as the average of the upper mixed layer, 0 to $30 \mathrm{~m}$ and 0 to $25 \mathrm{~m}$ of the water column at the PH50 and PH100 stations, respectively. The relationships between the physical and chemical variables, chl $a$, and the abundance of Noctiluca scintillans were analysed by correlation (data for Stn PH100 and PH50 pooled, except for correlations between Noctiluca abundance and abundance of dominant phytoplankton at Stn PH100). Stepwise multiple linear regression, using backward elimination $(\mathrm{p}<0.1)$ was subsequently used to model Noctiluca abundance at Stn PH100. For these regressions time-lagged variables were also included to account for the fact that Noctiluca may respond indirectly to changes in the physical and chemical variables because of its heterotrophy. The lag period was based on previously reported 'lag-periods' for heterotrophic dinoflagellate population growth responses to nutrient enrichment events (Hansen 1991, Painting et al. 1993, Nakamura et al. 1995), corresponding to the 'weekly' interval between sampling days (4 to $10 \mathrm{~d}$, average $6.8 \mathrm{~d}$ ). Ammonia data were excluded in the regression analyses since Noctiluca may influence ambient ammonia concentrations as described later in 'Discussion'. Models for Stn PH50 were also not determined since abundance data for dominant phytoplankton were not available. All data used for multiple linear regressions and correlations were log-transformed prior to analyses.

\section{RESULTS}

\section{Temporal variability in the physical and chemical variables, and phytoplankton abundance}

The physical, chemical and chl a data were summarised into 4 principal component factors (Table 1). These factors collectively accounted for $78 \%$ of the variation observed in the data set. Factor 1 showed high loadings $(>0.7)$ for temperature $(T)$, salinity $(S)$, $\mathrm{NO}_{2}^{-}+\mathrm{NO}_{3}^{-}, \mathrm{FRP}$ and $\mathrm{Si}$ in bottom water layers, and accounted for $35 \%$ of the variability. Factor 2 showed high loadings for $\mathrm{T}, \mathrm{NO}_{2}{ }^{-}+\mathrm{NO}_{3}{ }^{-}$, FRP and $\mathrm{Si}$ in surface water layers $(22 \%)$, while Factor 3 had high loadings for $\mathrm{NH}_{3}$ in surface and bottom water layers (12\%), and Factor 4 had high loadings for chl a in bottom water layers $(9 \%)$. The component loadings for levels of 
$\mathrm{S}$ and chl $a$ in surface water layers at Stn PH100 and PH50 were low $(<0.7)$. The 4 factors varied considerably during the austral spring and summer (September to February, mean coefficient of variation for the 4 factors $94 \%$ ) compared to the austral autumn and winter period (March to August, mean coefficient of variation for the 4 factors $63 \%$ ), consistent with the timing of the main hydrological events reported below.
A distinct seasonal hydrological cycle was observed during this study. Average surface water temperatures during the austral winter (July to August) were up to $6^{\circ} \mathrm{C}$ cooler than during the austral summer (December to February). The water column was thermally stratified from November to March (i.e. mainly during the austral summer), with the seasonal thermocline varying between depths of 20 to $40 \mathrm{~m}$ (Fig. 2A). Thermal
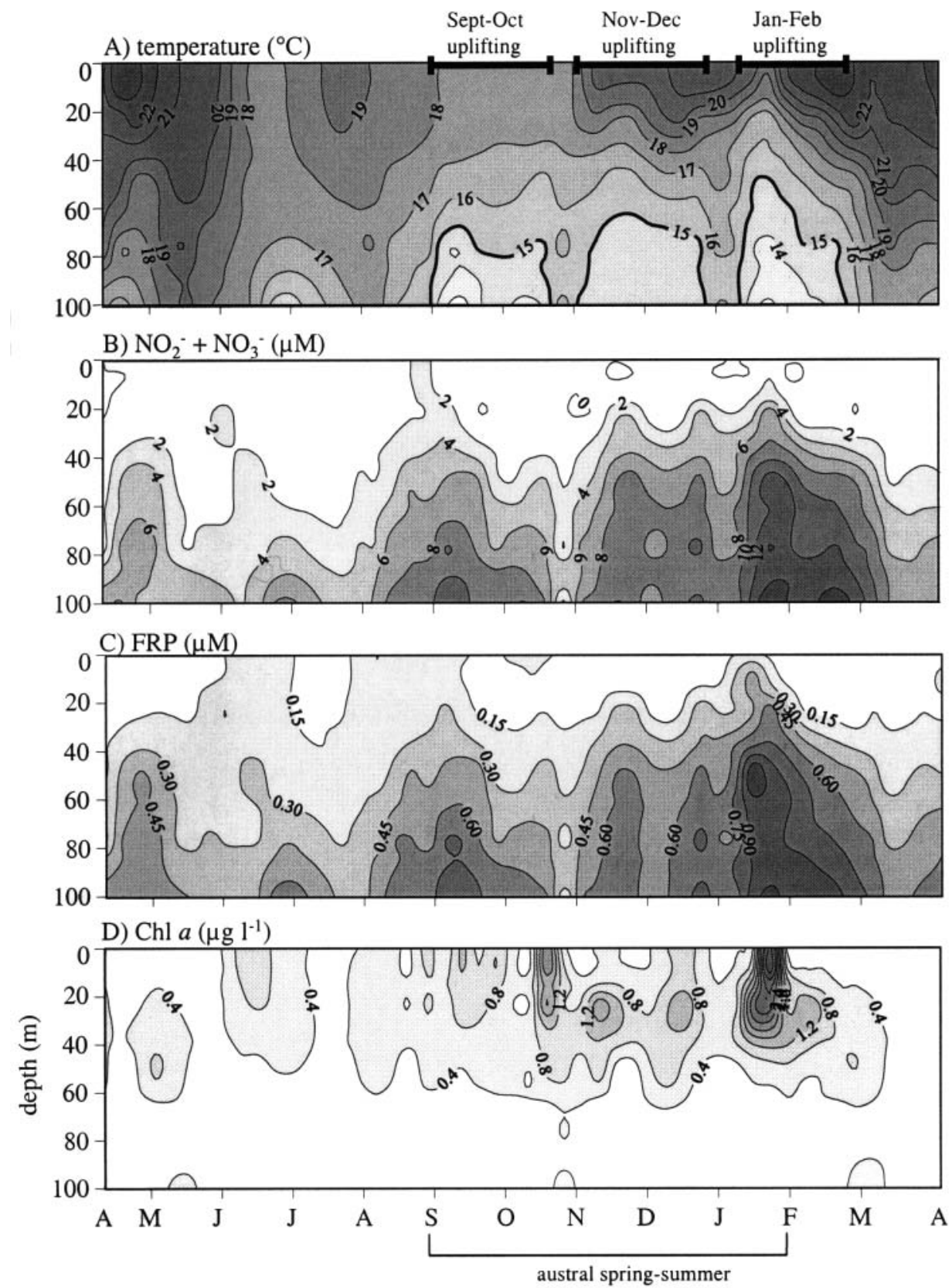

Fig. 2. (A) Contoured temperature; (B) oxidised nitrogen $\left(\mathrm{NO}_{2}{ }^{-}+\mathrm{NO}_{3}{ }^{-} \mu \mathrm{M}\right) ;(\mathrm{C})$ dissolved reactive phosphorus (FRP $\left.\mu \mathrm{M}\right)$; and (D) chlorophyll a $\left(\mathrm{chl} \mathrm{a} \mu \mathrm{g} \mathrm{l}^{-1}\right)$ data collected from Stn PH100 from March 1997 to March 1998. Bold isotherms on the temperature plot denote periods of uplifting that were defined by the doming of the isotherms and presence of cold water $\left(\leq 15^{\circ} \mathrm{C}\right)$ in the bottom water layers. The periods of uplifting are further indicated above the temperature plot 

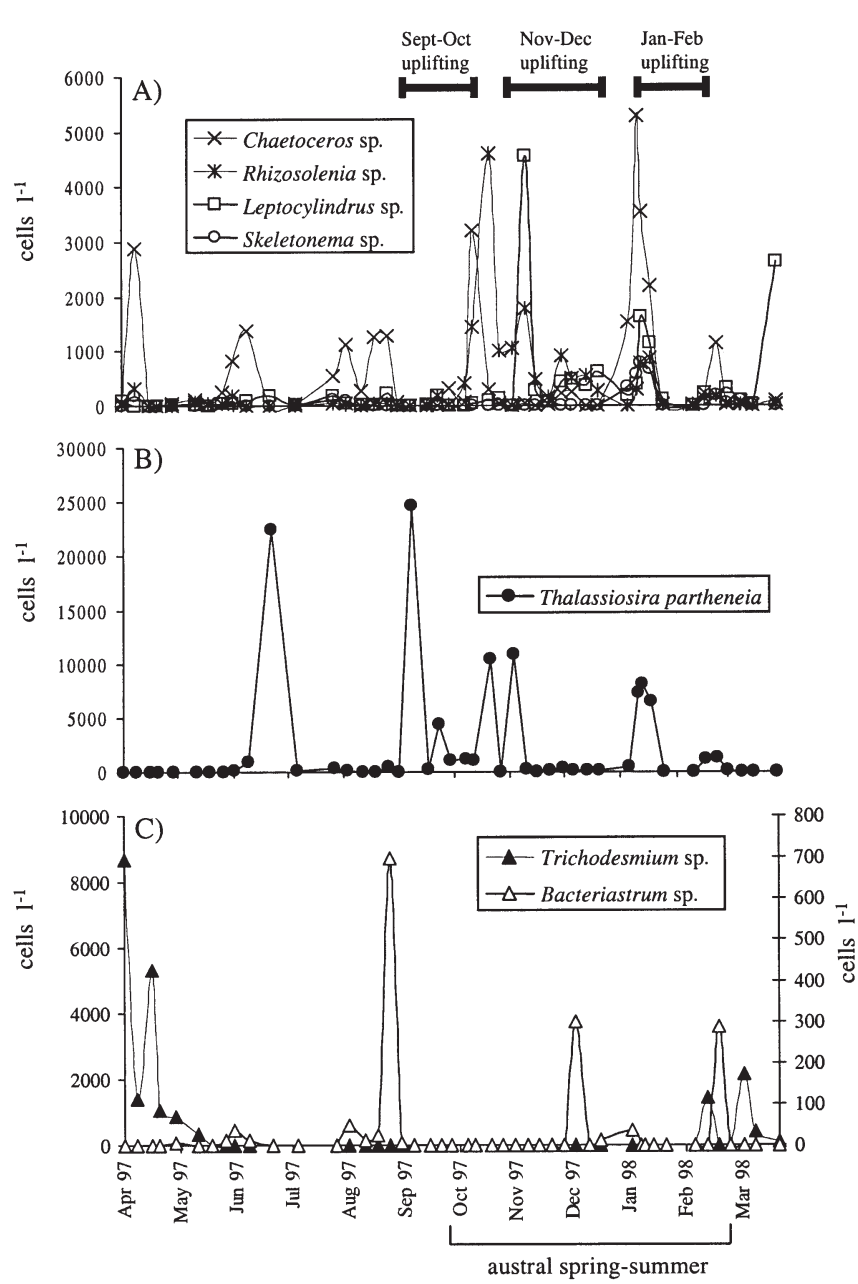

Fig. 3. (A,B) Abundance of dominant diatoms, and (C) tropical phytoplankton species at Stn PH100 from March 1997 to March 1998. Bacteriastrum sp. on secondary $y$-axis. The periods of uplifting are indicated above the plots

stratification was significantly correlated with a surface depletion and depth enrichment of nutrients (e.g. for temperature and $\mathrm{NO}_{2}{ }^{-}+\mathrm{NO}_{3}{ }^{-}, R=-0.75, \mathrm{p}<0.001$ ). There was a weak vertical nutrient gradient between the surface and bottom water layers during the austral autumn and winter (March to July), consistent with the absence of the thermocline. Three main uplifting events were also observed during the spring and summer months. The events occurred on 3 September to 10 October, 5 November to 22 December and 13 January to 19 February. The uplifting events were defined by the doming of the isotherms and the appearance of cold water $\left(\leq 15^{\circ} \mathrm{C}\right)$ in the bottom water layers (Fig. 2A). The cold-water intrusions were additionally correlated with high concentrations of $\mathrm{NO}_{2}^{-}+\mathrm{NO}_{3}^{-}$(max. 18.42 $\mu \mathrm{M}$ ) and FRP (max. $1.87 \mu \mathrm{M}$ ) in the bottom water layers, as shown for Stn PH100 (Fig. 2B,C). These trends were observed at Stn PH50.

Phytoplankton blooms occurred on 14 October (max. $2.9 \mathrm{~g} \mathrm{l}^{-1}$ ), 5 November (max. $2.1 \mathrm{\mu g}^{-1}$ ) and 13 Janu- ary (max. $7 \mu \mathrm{g} \mathrm{l}^{-1}$ ), but relatively high phytoplankton abundance persisted throughout the austral spring/ summer period (Fig. 2D), partly reflecting the long duration of the uplifting events. Several groups of phytoplankton were identified (Bacillariophyceae, Dinophyceae, Dictyophyceae, Coccolithophorids, and Cyanobacteria), but the greatest number of species (32) was represented in the Bacillariophyceae, which were also the most abundant group. The maximum abundance of the Bacillariophyceae was $2.4 \times 10^{4}$ cells $\mathrm{l}^{-1}$, compared to maximum abundances of only $0.3 \times$

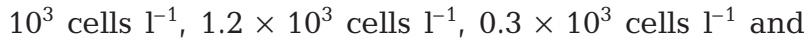
$8.7 \times 10^{3}$ cells $^{-1}$ for the Dinophyceae, Dictyophyceae, Coccothithophorids and Cyanobacteria, respectively. Of these less abundant groups, the Dinophyceae were the most taxonomically rich (represented by 25 species), while the other groups were only represented by 1 to 2 species.

The dominant genera within the diatom group were Chaetoceros, Leptocylindrus, Rhizosolenia, Skeletonema (Fig. 3A) and Thalassiosira (Fig. 3B). Thalassiosira partheneia dominated all the blooms observed in this study, being abundant even during the winter (Fig. 3B). T. partheneia bloomed immediately in response to all of the uplifting events, unlike the other genera, which bloomed 1 to 2 wk subsequent to the September-October uplifting, when surface water temperatures were up to $2^{\circ} \mathrm{C}$ cooler (Fig. 3B). In addition, not all of these genera bloomed in response to each uplifting event. Chaetoceros bloomed in October

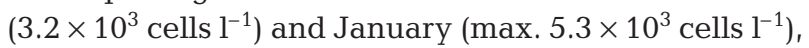
Rhizosolenia bloomed in October $\left(4.6 \times 10^{3}\right.$ cells $\left.\mathrm{l}^{-1}\right)$ and November $\left(1.8 \times 10^{3}\right.$ cells $\left.\mathrm{l}^{-1}\right)$, Leptocylindrus

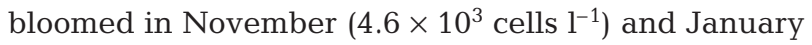
$\left(1.6 \times 10^{3}\right.$ cells $\left.1^{-1}\right)$ and Skeletonema bloomed only in January $\left(0.8 \times 10^{3}\right.$ cells $\left.\mathrm{l}^{-1}\right)$. Tropical phytoplankton species, such as the blue-green cyanobacteria Trichodesmium sp. and the diatom Bacteriastrum sp., were also conspicuous components of the phytoplankton community during the late summer and early autumn months either subsequent to or during the late stages of the January-February uplifting event (Fig. 3C). Bacteriastrum sp. was also abundant in late August to early September just prior to the September-October uplifting event. A peak in abundance of Bacteriastrum was observed in late November to early December, mid-way through the November-December uplifting event.

\section{Population structure of Noctiluca}

Noctiluca scintillans was twice as abundant at

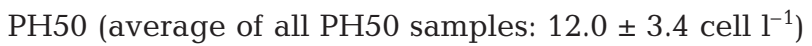
than at PH100 (average of all PH100 samples: $5.6 \pm$ 


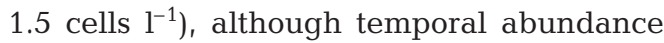
patterns were the same at both stations (Fig. 4A). Less than 1 cell $^{-1}$ was found between March and July, but from late August to late February, Noctiluca became abundant and sometimes even dominated the zooplankton community (Fig. 4A,B). In September, peak abundance of Noctiluca (32.2 cells $\mathrm{l}^{-1}$ ) was observed 2 wk subsequent to the T. partheneia bloom. In comparison, peak abundances of Noctiluca were greater in November ( 23.3 cells $\left.^{-1}\right)$ and January $\left(79.6\right.$ cells ${ }^{-1}$ ) and occurred at the same time as the T. partheneia blooms. Peaks in abundance of Noctiluca did not always correspond with the diatom blooms that occurred as a result of the uplifting events. For instance, the maximum abundance of Noctiluca (80.3 cells $\mathrm{l}^{-1}$ ) was observed on 2 December, when relatively high abundances of the tropical diatom Bacteriastrum were also observed (Figs. 3B \& 4A). Similar results were obtained during late August and late February.

An average of $77.6 \pm 2.9 \%$ (PH100 and PH50 data pooled, $\mathrm{n}=41$ ) of Noctiluca scintillans cells contained food particles in their vacuoles during the spring and summer months, in contrast to the autumn and winter, in which the average proportion of fed cells was only $44.6 \pm 6.7 \%$ (PH100 and PH50 data pooled, $\mathrm{n}=22$; Fig. $4 \mathrm{C}$ ). The dominant food item observed in the fed Noctiluca cells was Thalassiosira partheneia, but other food items such as the diatoms Rhizsolenia, Detonula, Chaetoceros, Guinardia, Coscinodiscus, Lauderia an unknown centric diatom, the dinoflagellate Ceratium, and copepod eggs and nauplii were observed in up to $55 \%$ of fed cells (Fig. 4C). T. partheneia was found in $80,70,45,100$ and $90 \%$ of fed cells sampled on 25 September, 5 November, 2 December, 13 January and 25 February, respectively. Only the relative number of cells reproducing was determined due to the daytime sampling. A greater proportion of cells was undergoing asexual reproduction in September $(1.6 \pm 1.1 \%$, PH100 and PH50 data pooled) compared to all other months $(0.04 \pm 0.02 \%$, PH100 and PH50 data pooled $)$. Swarmer-forming cells were found in August, September, January and February, but generally, these cells represented a low proportion $(12.1 \%)$ of the total number of cells reproducing.

Three groups or 'populations' of cells, based on abundance, dominance, cell diameter and nutritional
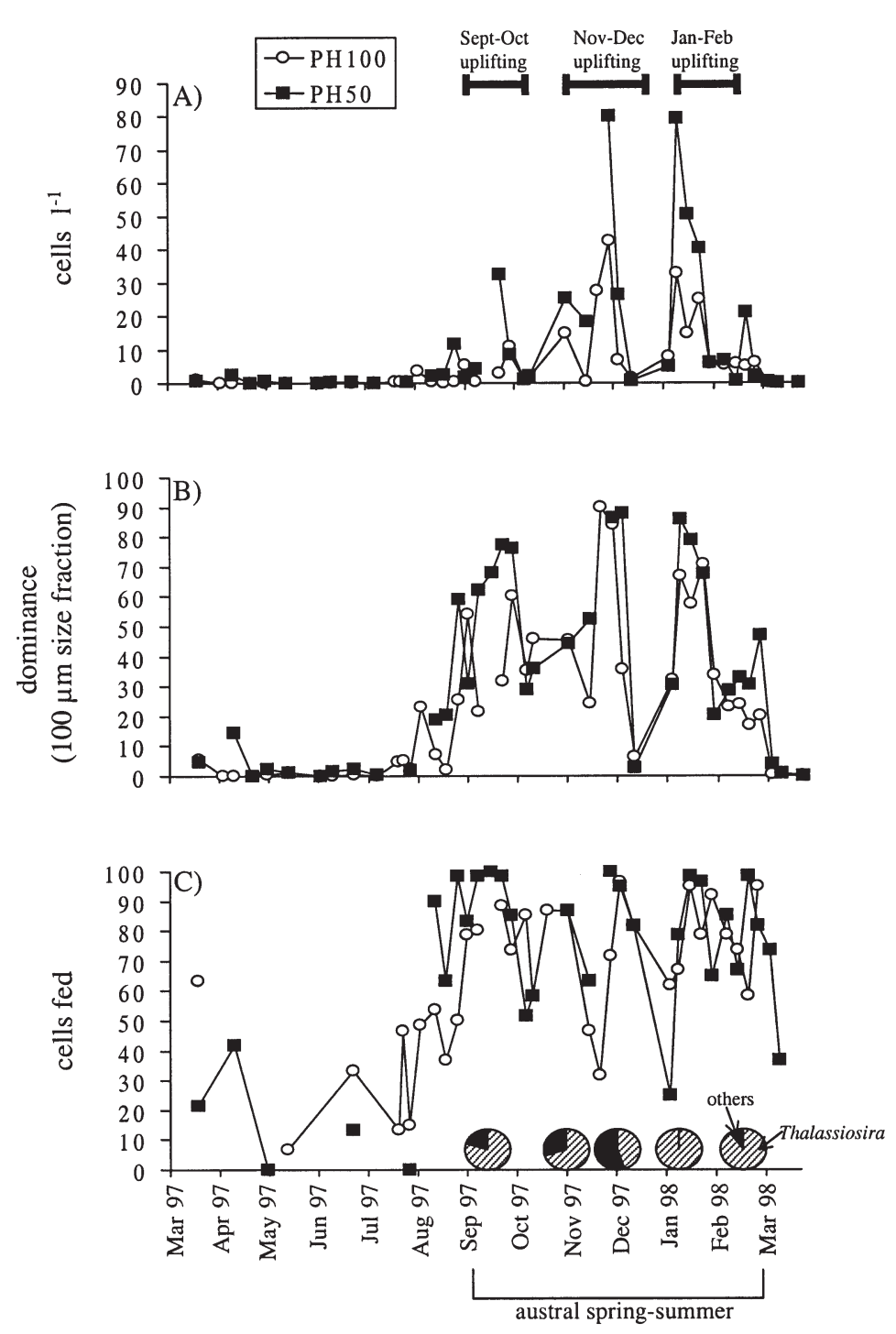

Fig. 4. (A) Abundance; (B) dominance (\%); and (C) proportion of fed cells (\%) of Noctiluca scintillans at Stns PH50 (ם) and PH100 (O) determined from March 1997 to 1998. Pie charts denote the proportion of Noctiluca scintillans cells that fed only on the diatom Thalassiosira partheneia and the proportion of Noctiluca scintillans cells that fed on other food items such as copepod nauplii and eggs, dinoflagellates and other diatoms. The 5 pie charts show data for samples collected on 25 September, 5 November, 2 December, 13 January and 25 February, when the abundance of Noctiluca scintillans was relatively high. The periods of uplifting are indicated above the abundance plot

status at a similarity level of $85 \%$, corresponded to winter samples, spring/summer samples and uplifting samples (Fig. 5). Cells sampled during the cooler months could be distinguished from cells sampled during the warmer months because they had lower nutritional status and smaller cell diameters. Cells sampled during the main uplifting events were distinguished 


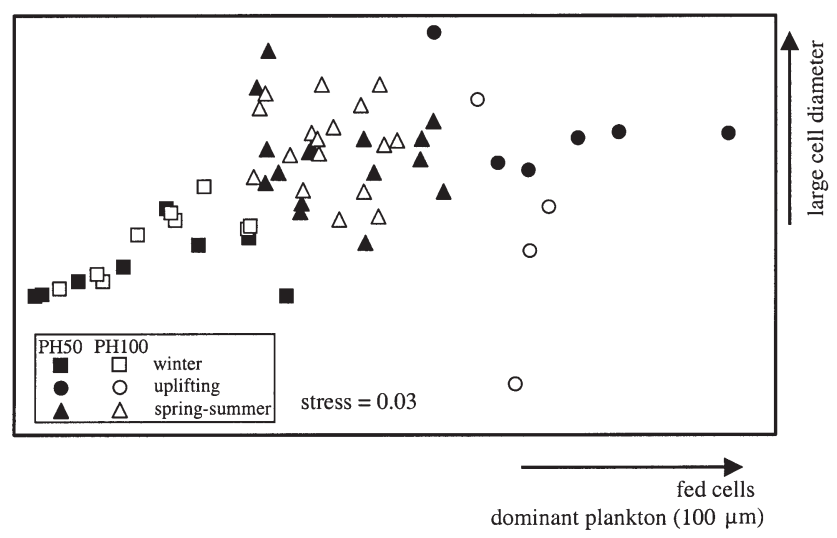

Fig. 5. Two-dimensional MDS ordination generated from abundance, percent dominance, cell diameter and nutritional status of Noctiluca scintillans at Stn PH50 (solid symbols) and

PH100 (open symbols) from March 1997 to March 1998

from those collected on other sampling dates since they had the highest nutritional status. The cell diameter of Noctiluca scintillans during the spring and summer varied considerably, including during the uplifting events (Fig. 5). Some cells were almost the same size as those constituting a red tide, while others were as small as those sampled during the autumn and winter. Pulses of small diameter cells (400 to $500 \mu \mathrm{m}$ ) were found at the start of the November-December and January-February uplifting events (Fig. 6). However, the largest cell diameters $(>600 \mu \mathrm{m})$ measured in this study were observed in samples collected during the September-October uplifting (Fig. 6).

\section{Physical, chemical and biological variables influencing the abundance of Noctiluca}

The single most important variable related to Noctiluca scintillans abundance was the $\mathrm{NH}_{3}$ content of the surface water layers (Table 2). Correlations between bottom water variables $\left(\mathrm{Si}_{\mathrm{B}}\right.$, Factor $1, \mathrm{NO}_{2}^{-}+$ $\mathrm{NO}_{3}{ }_{\mathrm{B}}{ }, \mathrm{T} \mathrm{B}$ ) and Noctiluca abundance were the next highest. In contrast, Noctiluca abundance was poorly correlated with surface water variables (e.g. $\mathrm{NO}_{2}^{-}+$ $\mathrm{NO}_{3}{ }_{\mathrm{S}}$, Factor $2, \mathrm{~T}_{\mathrm{S}}$, chl $a_{\mathrm{S}}$ ) other than $\mathrm{NH}_{3}$.

Multiple linear regressions generated from unlagged variables indicated that the more influential group of variables that accounted for the observed abundance patterns of Noctiluca scintillans in this study were $\mathrm{T}_{\mathrm{B}}$, $\mathrm{T}_{\mathrm{S}}, \mathrm{S}_{\mathrm{B}}, \mathrm{Si}_{\mathrm{B}}$, Thalassiosira and Chaetoceros (all of these

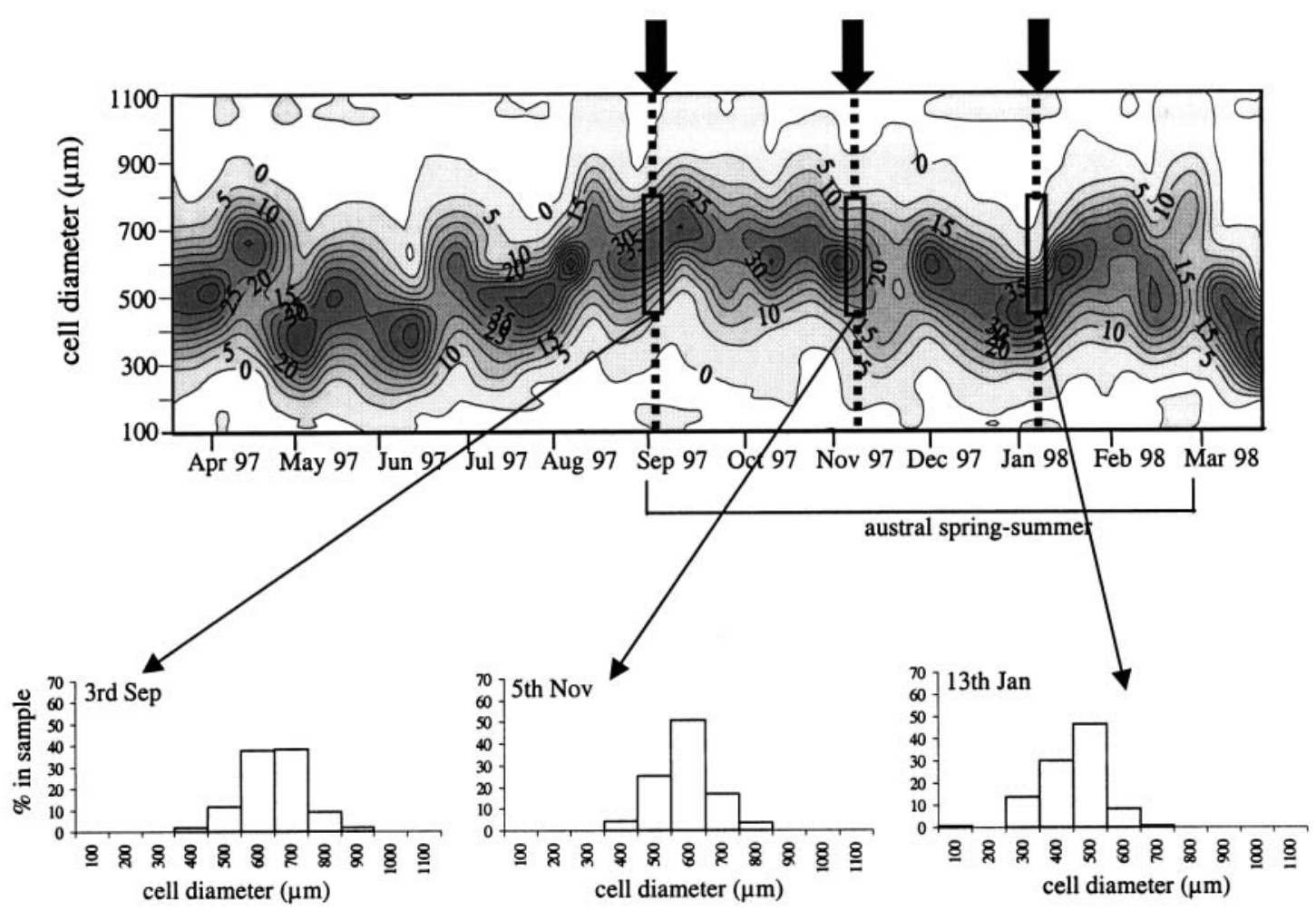

Fig. 6. Contour plot of the cell diameter of Noctiluca scintillans from March 1997 to March 1998 (data for Stns PH50 and PH100 were pooled). Contours represent the percentage of cells categorised into each size class. The cell size data were categorised into $100 \mu \mathrm{m}$ size class intervals. Cell size frequency histograms of Noctiluca cells collected at the start of the 3 main uplifting events are plotted below. Black arrows above the contour plot denote the start of the 3 main uplifting events 

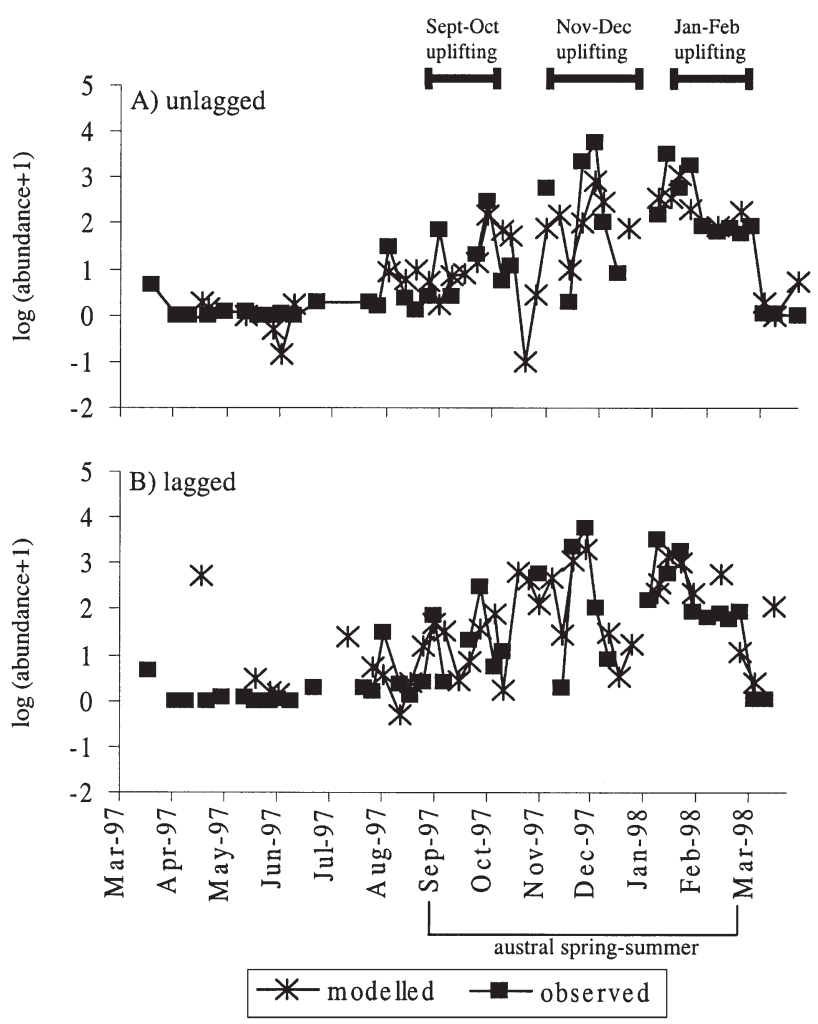

Fig. 7. Multiple linear regression models of (A) unlagged and (B) lagged (4 to $10 \mathrm{~d}$ ) of physical, chemical and biological data collected at Stn PH100 between March 1997 and March 1998. The periods of uplifting are indicated above the plots
Table 2. Correlation coefficients (r) between Noctiluca scintillans abundance and physical, chemical and biological variables, including factor scores generated for each principal component factor and dominant phytoplankton genera (at Stn PH100 only). All data for Stns PH100 and PH50 were pooled (except for correlations between Noctiluca abundance and dominant phytoplankton abundance at station PH100) and log transformed prior to analyses. Subscripts B and S denote bottom and surface layers of the water column respectively

\begin{tabular}{|lcc|}
\hline Variable & Noctiluca abundance & $\mathrm{p}$ \\
\hline Factor 1 & 0.50 & $<0.001$ \\
Factor 2 & -0.01 & 0.87 \\
Factor 3 & 0.44 & $<0.001$ \\
Factor 4 & -0.11 & 0.13 \\
$\mathrm{~T}_{\mathrm{B}}$ & -0.45 & $<0.001$ \\
$\mathrm{~T}_{\mathrm{S}}$ & -0.02 & 0.14 \\
$\mathrm{~S}_{\mathrm{B}}$ & -0.36 & $<0.001$ \\
$\mathrm{~S}_{\mathrm{S}}$ & -0.30 & 0.04 \\
$\mathrm{FRP}_{\mathrm{B}}$ & 0.35 & 0.02 \\
$\mathrm{FRP}_{\mathrm{S}}$ & 0.11 & 0.18 \\
$\mathrm{NO}_{2}{ }^{-}+\mathrm{NO}_{3}{ }_{\mathrm{B}}^{\mathrm{B}}$ & 0.45 & 0.03 \\
$\mathrm{NO}_{2}{ }^{-}+\mathrm{NO}_{3}{ }^{-}$ & 0.01 & 0.54 \\
$\mathrm{NH}_{3 \mathrm{~S}}$ & 0.20 & 0.22 \\
$\mathrm{NH}_{3 \mathrm{~S}}$ & 0.54 & $<0.001$ \\
$\mathrm{Si}_{\mathrm{B}}$ & 0.52 & $<0.001$ \\
$\mathrm{Si}_{\mathrm{S}}$ & -0.15 & 0.54 \\
chl a $_{\mathrm{B}}$ & 0.03 & 0.23 \\
chl a & 0.10 & $<0.001$ \\
Chaetoceros sp. & 0.16 & 0.35 \\
Leptocylindrus sp. & 0.14 & 0.40 \\
Protoperidinium sp. & 0.14 & 0.40 \\
Rhizosolenia sp. $_{\text {Skeletonema sp. }}$ & 0.40 & 0.02 \\
Thalassiosira sp. & 0.37 & 0.02 \\
& 0.20 & 0.23 \\
\hline
\end{tabular}

data were log transformed, as were the Noctiluca data; Table 3A). This unlagged model accounted for $66.5 \%$ of the variance observed in the present Noctiluca counts (Fig. 7A). The unlagged model suggested that the highly stratified water column (low $\mathrm{T}_{\mathrm{B}}$, high $\mathrm{T}_{\mathrm{S}}$ ), containing high levels of $\mathrm{Si}$ and $\mathrm{S}$ in bottom water layers and high numbers of small centric diatoms (Chaetoceros and Thalassiosira) in surface water layers, prevailed when abundance of NoCtiluca was high. The most important variables relating to Noctiluca abundance in this unlagged model were $T_{B}$, $\mathrm{S}_{\mathrm{B}}, \mathrm{Si}_{\mathrm{B}}$, which had higher standardised coefficients.

The lagged model produced a similar correlation coefficient $(r=0.68$; adjusted $r=0.61$ ) and similar tolerance levels for each variable, to the unlagged model (Table 3B, Fig. 7A). The lagged model indicated that numbers of NoC-
Table 3. (A) Multiple linear regression output of unlagged physical, chemical and biological data collected at Stn PH100 from March 1997 to March 1998. Dependent variable $=$ Noctiluca scintillans abundance, $\mathrm{n}=28, \mathrm{r}^{2}=0.82, \mathrm{r}=0.67$, adjusted $r=0.57$. (B) Multiple linear regression output of lagged (4 to $10 \mathrm{~d}$ ) physical, chemical and biological data collected at Stn PH100 from March 1997 to March 1998. Dependent variable $=$ Noctiluca scintillans abundance, $\mathrm{n}=26$, $r^{2}=0.82, r=0.68$, adjusted $r=0.61$

\begin{tabular}{|lccccc|}
\hline Variable & Coefficient & $\begin{array}{c}\text { Standardised } \\
\text { coefficient }\end{array}$ & Tolerance & $F$ & $\mathrm{p}$ \\
\hline (A) & & & & & \\
Constant & $-1628.70 \pm 668.40$ & 0.00 & - & - & 0.02 \\
$\mathrm{~T}_{\mathrm{B}}$ & $-16.00 \pm 5.80$ & -1.41 & 0.06 & 6.62 & 0.01 \\
$\mathrm{~T}_{\mathrm{S}}$ & $6.17 \pm 2.36$ & 0.46 & 0.53 & 6.63 & 0.02 \\
$\mathrm{~S}_{\mathrm{B}}$ & $456.48 \pm 189.37$ & -1.30 & 0.06 & 5.57 & 0.03 \\
$\mathrm{Si}_{\mathrm{B}}$ & $2.44 \pm 0.83$ & 0.62 & 0.36 & 7.75 & 0.01 \\
Thalassiosira $\mathrm{sp}$. & $0.19 \pm 0.08$ & 0.41 & 0.54 & 5.03 & 0.03 \\
Chaetoceros $\mathrm{sp}$. & $0.11 \pm 0.06$ & 0.26 & 0.77 & 3.15 & 0.09 \\
$\mathbf{( B )}$ & & & & & \\
Constant & $1105.36 \pm 390.76$ & 0.00 & - & - & 0.01 \\
$\mathrm{~S}_{\mathrm{S}}$ & $-305.43 \pm 108.07$ & -0.42 & 0.69 & 7.99 & 0.01 \\
chl a & $-3.12 \pm 1.36$ & -0.38 & 0.57 & 5.28 & 0.03 \\
$\mathrm{Si}_{\mathrm{B}}$ & $1.00 \pm 0.48$ & 0.35 & 0.57 & 4.39 & 0.05 \\
$\mathrm{Si}_{\mathrm{S}}$ & $-2.15 \pm 0.44$ & -0.75 & 0.66 & 24.19 & $<0.001$ \\
\hline
\end{tabular}




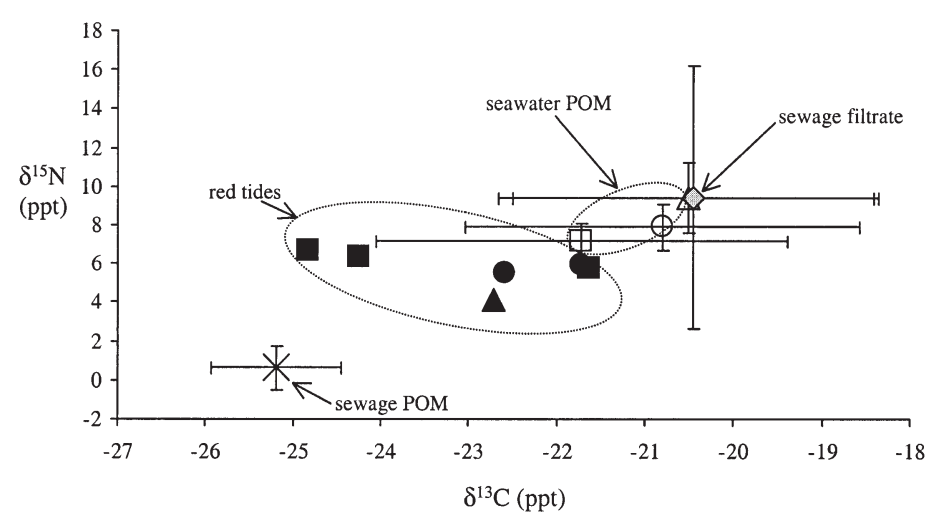

Fig. 8. Stable isotope ratios of carbon and nitrogen in Noctiluca scintillans red tide samples (solid symbols) and seawater particulate organic matter (POM) samples $(\mathrm{n}=12$, open symbols) collected from Sydney (squares), and from regions north (triangles) and south of Sydney (circles). These were compared to the stable isotope ratios of carbon and nitrogen in sewage filtrate (diamonds) and sewage POM (crosses) collected from Sydney's 3 main sewage treatment plants. The plotted values for seawater POM, sewage POM and sewage filtrate are the means $( \pm \mathrm{SE})$ of 12,16 and 13 samples, respectively

tiluca scintillans were correlated with low levels of S and $\mathrm{Si}$ in surface water layers, low levels of chl a in bottom water layers, and high levels of $\mathrm{Si}$ in the bottom water layers of the previous 4 to $10 \mathrm{~d}$. The standardised coefficients for these lagged variables were almost equally weighted except for $\mathrm{Si}_{\mathrm{S}}$, which had a higher coefficient (Table 3B).

\section{Stable isotope signature of red tides}

More than $80 \%$ of red tides reported during this study occurred in the summer months, usually when the weather and sea conditions were calm and stable (Table 4). Most of the red tides were sighted in coastal marine waters off Sydney, and downstream to the south coast of NSW. These red tide cells had larger cell diameters (674 to $771 \mu \mathrm{m}$ ) than those sampled north of Sydney such as in Port Stephens (574 $\mu \mathrm{m}$; Table 4). The average size of red tide cells $(673 \pm 29.2 \mu \mathrm{m})$ was significantly smaller than the size of the cells collected during the uplifting events $\left(513.4 \pm 40.2 \mu \mathrm{m}_{i} F=12.39\right.$, $\mathrm{p}=0.005$, ANOVA). In addition, the red tide cells did not contain any food particles.

The stable isotope ratios of carbon and nitrogen $\left({ }^{13} \mathrm{C}:{ }^{12} \mathrm{C},{ }^{15} \mathrm{~N}:{ }^{14} \mathrm{~N}\right)$ of red tide samples collected in various regions of the NSW coast during various times of the year were similar (Fig. 8). Mean $\delta^{13} \mathrm{C}$ and $\delta^{15} \mathrm{~N}$ of red tide cells were $-22.96 \pm 0.6 \mathrm{ppt}$ and $5.74 \pm 0.4 \mathrm{ppt}$, respectively. The $\delta^{13} \mathrm{C}$ (range -25.86 to $-18.34 \mathrm{ppt}$ ) and $\delta^{15} \mathrm{~N}$ (range 5.89 to $10.68 \mathrm{ppt}$ ) of seawater particulate organic matter (POM, >0.2 $\mu \mathrm{m}$ size fraction) was generally greater than those of the red tide cells and highly variable (Fig. 8). Hence, there appeared to be little

Table 4. Red tides of Noctiluca scintillans reported along the southeast coast of NSW, Australia, from March 1997 to March 1998. $\mathrm{E}=$ estuarine, $\mathrm{M}=$ marine, $\mathrm{SYD}=$ Sydney, $\mathrm{NTH}=$ north of Sydney, $\mathrm{STH}=$ south of Sydney

\begin{tabular}{|c|c|c|c|c|c|c|}
\hline Date & Location & Region & Water body & $\begin{array}{c}\text { Weather/sea } \\
\text { conditions }\end{array}$ & Sample & $\begin{array}{l}\text { Diameter }(\mu \mathrm{m}) \\
(\text { mean } \pm \mathrm{SE})\end{array}$ \\
\hline Apr 97 & Botany Bay & SYD & $\mathrm{E}$ & NNW, 7kt & - & - \\
\hline Apr 97 & Lake Macquarie & NTH & $\mathrm{E}$ & - & - & - \\
\hline Aug 97 & Bass Point & STH & M & WSW, $25 \mathrm{kt}$ & - & - \\
\hline Sep 97 & St. Georges Basin & $\mathrm{STH}$ & $\mathrm{E}$ & $\mathrm{NE}, 3 \mathrm{kt}$ & - & - \\
\hline Sep 97 & Otford \& Werrong & STH & M & $\mathrm{NE}, 5 \mathrm{kt}$ & - & - \\
\hline Oct 97 & Newcastle & NTH & M & NW, $13 \mathrm{kt}$ & - & - \\
\hline Dec 97 & Illawarra & STH & M & $\mathrm{S}, 15 \mathrm{kt}$ & - & - \\
\hline Dec 97 & Sydney (northern beaches) & SYD & M & NNE, $19 \mathrm{kt}$ & - & - \\
\hline Dec 97 & Port Stephens & $\mathrm{NTH}$ & M & - & $\mathrm{X}$ & $573.95 \pm 10.40$ \\
\hline Jan 98 & Sydney (northern beaches) & SYD & M & $\mathrm{NNE}, 16 \mathrm{kt}$ & - & - \\
\hline Jan 98 & Central coast & NTH & M & $\mathrm{SE}, 0-10 \mathrm{kt}$, calm & - & - \\
\hline Jan 98 & Stanwell Park to Kiama & STH & M & $\mathrm{S}, 10 \mathrm{kt}$ & $\mathrm{X}$ & $653.38 \pm 4.41$ \\
\hline Jan 98 & Cronulla & SYD & M & $\mathrm{SE}, 11 \mathrm{kt}$ & $\mathrm{X}$ & $706.76 \pm 4.66$ \\
\hline Jan 98 & Illawarra & $\mathrm{STH}$ & M & no wind, calm seas & $\mathrm{X}$ & $659.31 \pm 20.67$ \\
\hline Jan 98 & Batemans Bay & STH & M & - & - & - \\
\hline Feb 98 & Cronulla & SYD & M & NNE, 6 kt & $\mathrm{X}$ & $674.15 \pm 6.17$ \\
\hline Feb 98 & Illawarra & STH & M & no wind, calm seas & - & - \\
\hline Feb 98 & Whale beach & SYD & M & $\mathrm{NE}, 9 \mathrm{kt}$ & - & - \\
\hline Feb 98 & Collaroy & SYD & M & $\mathrm{SSE}, 9 \mathrm{kt}$ & - & - \\
\hline Mar 98 & Sydney & SYD & M & E, $8 \mathrm{kt}$ & $\mathrm{X}$ & $771.64 \pm 9.60$ \\
\hline Mar 98 & Coffs Harbour & NTH & M & $\mathrm{SSW}, 7 \mathrm{kt}$ & - & - \\
\hline
\end{tabular}


variation in the $\delta^{13} \mathrm{C}$ and $\delta^{15} \mathrm{~N}$ of POM samples collected at the vicinity of a shore-based sewage outfall in Sydney compared to reference sites in Port Stephens and Jervis Bay. Sewage POM had a relatively stable $\delta^{13} \mathrm{C}$ and $\delta^{15} \mathrm{~N}$ of $-25.19 \pm 0.74 \mathrm{ppt}$ and $0.62 \pm 0.29 \mathrm{ppt}$, respectively (Fig. 8), while that of sewage filtrate was highly variable, at times exceeding the $\delta^{13} \mathrm{C}$ and $\delta^{15} \mathrm{~N}$ of red tide and seawater POM samples (Fig. 8).

\section{DISCUSSION}

\section{Population growth of Noctiluca}

Temporal distribution patterns of Noctiluca scintillans in this study were consistent with patterns previously reported in northern hemisphere waters (Takayama 1984, Uhlig \& Sahling 1990). Maximum abundance of Noctiluca occurred in the spring and summer and was always followed by a rapid breakdown of the population in autumn. Thereafter, the abundance of Noctiluca remained relatively low during winter. Inter-annual variations in this temporal distribution pattern were minimal in the North Sea, where long-term field studies on Noctiluca have been conducted (Uhlig \& Sahling 1990). These long-term studies suggest that this temporal distribution pattern was a seasonal periodicity due to the seasonal overturn of water masses.

By comparison to northern hemisphere waters, a similar distinct seasonal hydrological cycle was obtained in the near shore waters off Port Hacking. However, as commonly occurs during the austral spring and summer months (Rochford 1975, 1984, Tranter et al. 1986), the cycle was interrupted by intrusions of cold, nutrientrich water, uplifted from the continental slope. These uplifting events were the basis for the variation in the levels of nutrients (FRP, $\mathrm{NO}_{2}{ }^{-}+\mathrm{NO}_{3}{ }^{-}$, $\mathrm{Si}$ ), temperature and salinity in the bottom water layers at Stns PH50 and PH100. There were 3 main uplifting events during this study, all of which were accompanied by an increase in abundance of phytoplankton (predominantly diatoms). Whenever the uplifting events occurred, a diatom bloom followed either immediately (November-December, January-February events) or within 1 to $2 \mathrm{wk}$ of the event (September-October event). The difference in the response time of the phytoplankton to each uplifting event was related to warmer water temperatures during the summer, which increased the growth rates of the phytoplankton (Venrick 1993). These findings are similar to those reported in previous studies of this region, which show that the underlying mechanism for phytoplankton growth along the south-east coast of Australia is indeed the uplifting of slope water (Hallegraeff \& Reid 1986, Hallegraeff \& Jeffrey 1993).
Whilst abundance of Noctiluca scintillans was generally high during the spring and summer, irregular peaks in the abundance of Noctiluca during this period were related to the diatom blooms that resulted from the uplifting events. These irregular peaks differed from the single broad spring and summer peak in the abundance of Noctiluca in the North Sea and South China Sea (Uhlig \& Sahling 1990, Huang \& Qi 1997). The multiple linear regression models and the correlations between Noctiluca abundance and the environmental variables support our observations. Factor 1, which may be interpreted as an uplifting index since it displayed high component loadings for variables that are indicative of slope water ( $\mathrm{T}, \mathrm{S}, \mathrm{FRP}, \mathrm{NO}_{2}{ }^{-}+\mathrm{NO}_{3}{ }^{-}$and $\mathrm{Si}$ in bottom water layers), was one of the most highly correlated variables to Noctiluca abundance. Only 2 other variables, $\mathrm{NH}_{3}$ levels in surface water layers and Si levels in bottom water layers, had stronger correlations with the Noctiluca counts. The temporal variability in the latter variable $\left(\mathrm{Si}_{\mathrm{B}}\right)$ was related to uplifting of slope water at the study sites. The positive correlation between NoCtiluca abundance and the $\mathrm{NH}_{3}$ levels in surface waters may be purely due to autochthonous nutrient generation by Noctiluca cells (Montani et al. 1998) that contain high levels of ammonia in their vacuoles (Elbratcher \& Qi 1998). Thus, from these results alone, it can be concluded that the mechanism underlying rapid population growth of Noctiluca during the present study was uplifting of nutrient-rich slope water.

The combination of variables within the unlagged model (i.e. at the time of sampling) reflected 'postuplifting' conditions (high phytoplankton biomass and strong thermal stratification), while those in the lagged model reflected 'initial uplifting' conditions (depth enrichment of nutrients). These models highlight the heterotrophic response of Noctiluca scintillans to the uplifting events. At most, the models accounted for $68 \%$ of the variability observed in the Noctiluca counts. Much of the unexplained variance is likely to have resulted from the difficulty in identifying predictor variables from a data set collected from a dynamic hydrological setting. Each uplifting event persisted for at least 1 mo and was followed by another event within $\sim 3 \mathrm{wk}$. The long duration and quick succession of the events would have increased the difficulty in discerning the biological response from an individual uplifting event. It would be worthwhile to investigate the validity of both models using an independent data set.

\section{Temporal variation in the population structure of Noctiluca}

The very few Noctiluca scintillans cells found during the austral winter in the present study were starved, 
similar to the winter Noctiluca populations in the German Bight (Uhlig \& Sahling 1990). The rapid increase in the number of cells containing food particles during the austral spring and summer may be interpreted as a result of the increased availability of food (predominantly Thalassiosira) arising from the uplifting events. Indeed, in the present study, a distinct Noctiluca population comsisting entirely of fed cells was identified during the uplifting events (Fig. 5). These conclusions are based solely on measurements of food prevalence, and therefore other explanations may be also possible e.g. slow digestion. The findings are, however, consistent with those obtained from laboratory cultures of Noctiluca which show that Noctiluca cells that are provided with sufficient food contain prominent food vacuoles (Hanslik 1987, Buskey 1995). The laboratoryfed cells have also been shown to undergo rapid cell division, while starved cells no longer divide (Elbratcher \& Qi 1998). Food availability therefore appears to be an important determinant for positive population growth of Noctiluca. The results of the present study did not show a negative correlation between Noctiluca abundance and chl a concentration, as reported for Noctiluca populations in the South China Sea (Huang \& Qi 1997), where it has been suggested that Noctiluca populations exert a significant feeding pressure on the phytoplankton community. The disparity between the 2 studies is probably due to the number of Noctiluca cells present in the water column. Whilst both studies report similar chl a levels, the maximum number of Noctiluca cells observed in the South China Sea was 3 orders of magnitude greater than the maximum observed in the present study.

Cell diameters of Noctiluca scintillans were useful for identifying the origin of the cells (Murray \& Suthers 1999). Cells with large diameters, such as those that constitute a red tide, are considered to be old and in poor condition and close to the end of population growth (Uhlig \& Sahling 1990). These large old cells have been circulating in the sea for a relatively long time and thus must have been transported from spatially and/or temporally distant water masses (Huang \& Qi 1997, Murray \& Suthers 1999). In the present study, pulses of small-sized cells $(<600 \mu \mathrm{m})$ coincided well with the timing of the uplifting events in NovemberDecember and January-February, implying in situ population growth of Noctiluca. The large diameter of the cells in the September-October samples suggested that the cells originated elsewhere. Since the surface water layers of inshore waters were flowing southwards for $70 \%$ of the time in August-September, as deduced from the Ocean Reference Station data, it was hypothesised that the large cells originated north of the study site. Red tide samples collected from the northern regions of the NSW coast had the smallest cell dia- meters of all bloom material, suggesting a younger bloom closer to the region of growth. Also consistent with the hypothesis were the relatively high numbers of the tropical phytoplankton, Bacteriastrum sp., in samples collected in late August and early September. These tropical diatoms originate from the Coral Sea in the northeastern part of Australia and are frequently transported southward with the East Australian Current (Hallegraeff \& Reid 1986). The peak in abundance of Noctiluca in early December and late February may have also partly resulted from an accumulation of advected cells from the north, since relatively high numbers of Bacteriastrum cells were observed in the phytoplankton samples collected during these times.

A high proportion of swarmer-forming cells was found amongst the old and poor conditioned Noctiluca scintillans population in September-October. Swarmerforming cells were also found during late January to early February, when the proportion of cells capable of growth (i.e. those with cell diameters smaller than those of red tide cells, $<600 \mu \mathrm{m}$ ) decreased to $<40 \%$. Noctiluca cells undergo swarmer formation after 22 to 24 binary fissions (Sato et al. 1998). This cycle is not altered by varying levels of temperature, salinity, light, $\mathrm{pH}$, or by the nutritional status of the cells. Rather, a high abundance of cells suppresses swarmer formation (Sato et al. 1998). These laboratory findings may provide insight into our field results, which show an apparently unusual pattern of low abundance of swarmer cells at the peak of population growth. The field results initially appeared unusual, since the formation of swarmer mother cells would have been an effective means of rapid population growth, given that a single swarmer mother cell may release up to $2^{11}$ swarmers (Sato et al. 1998).

\section{Noctiluca red tides and eutrophication}

The results presented to this point suggest that natural nutrient enrichment processes promote population growth of Noctiluca scintillans, irrespective of continuous sewage flows off Sydney. The stable isotope data, which were used to trace the underlying nutrient source for the prey of Noctiluca provide further support for this conclusion. The isotopic similarity of the red tide cells collected from spatially and temporally distant water masses suggest that the prey of Noctiluca were derived from a single nutrient source, most likely uplifted slope water. Indeed, the slope water enrichments persisted for $65 \%$ of the spring and summer months and occurred over length scales covering hundreds of kilometres with apparent continuity (Pritchard \& Lee 2001), encompassing regions in which red tide samples were collected. Although only epi- 
sodic, these natural oceanic nutrient sources have been known to overwhelm anthropogenic nutrient loads off Sydney (Pritchard \& Lee 2001). In contrast, while the stable isotope signatures of sewage POM remained constant over time, the differences between the $\delta^{15} \mathrm{~N}$ and $\delta^{13} \mathrm{C}$ of sewage POM and red tide cells were either greater than 1 trophic level increase, as seen in the $\delta^{15} \mathrm{~N}$ values, or too high, as seen in the $\delta^{13} \mathrm{C}$ values. These differences are greater than the predictable step-wise isotopic enrichment between prey and consumer tissues (e.g. Rau 1982, Wada et al. 1987 , Fry 1988). The present study therefore found no evidence to suggest that sewage POM was a dominant prey source for Noctiluca during the spring and summer. The study did find that while slope water enrichments have historically triggered specific successions of diatom blooms along the NSW coast, these enrichment processes have not been associated with Noctiluca growth to the same extent or frequency as observed in the present study (Jeffrey \& Carpenter 1974, Hallegraeff \& Reid 1986, Hallegraeff \& Jeffrey 1993). In these previous studies, Noctiluca cells were found in samples collected during the spring and summer months in which the uplifting events occurred, but on these occasions, Noctiluca was not considered to be a dominant blooming species, as shown in the present study. Furthermore, the year-round presence of Noctiluca reported in the present study appears to be unprecedented for this region. The incidence and intensity of uplifting events reported in the present study was similar to that reported in the study of Hallegraeff \& Reid (1986). The most notable difference between the results of the present study and those reported in Hallegraeff \& Reid (1986) was a shift in the dominant diatom genera to Thalassiosira, an optimal food source for Noctiluca (Buskey 1995). This shift is likely to be the most probable cause for the increase in Noctiluca numbers over time (Ajani et al. 2001b). Clearly, further studies are required to determine the cause(s) for this shift. The current data show that this shift was not associated with an increase in nutrient levels or with a change in stoichiometric nutrient ratios over time.

Acknowledgements. The authors are grateful to R. Smith, the captain of the Environment Protection Authority RV 'Glaucus'. We thank the scientific crew members, S. Murray, S. Wallace, D. Andrew, R. Piola and T. Gaston. M. Krogh provided advice with the statistical analyses of the data. We thank J. Middleton, J. Benzie, G. Reed and M. Dickman for reviewing the initial drafts of this manuscript. We are also grateful to the anonymous reviewers for their careful and constructive criticism of this work. Financial support for this work was provided by the New South Wales Environment Protection Authority, Water Science Section. This research was conducted whilst J.D.-C. was in receipt of an Australian Postgraduate Award (Industry).

\section{LITERATURE CITED}

Ajani P, Hallegraeff GM, Pritchard T (2001a) Historic overview of algal blooms in marine and estuarine waters of New South Wales, Australia. Proc Linnean Soc NSW 123: $1-22$

Ajani P, Lee R, Pritchard T, Krogh M (2001b) Phytoplankton patterns at CSIRO's long-term coastal station off Sydney. J Coast Res 34:60-73

Buskey EJ (1995) Growth and bioluminescence of Noctiluca scintillans on varying algal diets. J Plankton Res 17(1): $29-40$

Clarke KR (1993) Non-parametric multivariate analysis of changes in community structure. Aust J Ecol 18:117-143

Elbrachter M, Qi YZ (1998) Aspects of Noctiluca (Dinophyceae) population dynamics. In: Anderson DM, Cembella AD, Hallegraeff MG (eds) Physiological ecology of harmful algal blooms. NATO ASI Series, Vol G 41. Springer-Verlag, Berlin, p 315-335

Fry B (1988) Food web structure on Georges Bank from stable $\mathrm{C}, \mathrm{N}$ and $\mathrm{S}$ isotopic compositions. Limnol Oceanogr 33: $1182-1190$

Hallegraeff GM (1993) A review of harmful algal blooms and their apparent global increase. Phycologia 32:79-99

Hallegraeff GM (1995) Algal blooms in Australian coastal waters. Water July/August 20-23

Hallegraeff GM, Jeffrey SW (1993) Annually recurrent diatom blooms in spring along the New South Wales coast of Australia. Aust J Mar Freshw Res 44:325-34

Hallegraeff GM, Reid DD (1986) Phytoplankton species successions and their hydrological environment at a coastal station off Sydney. Aust J Mar Freshw Res 37:361-377

Hansen PJ (1991) Quantitative importance and trophic role of heterotrophic dinoflagellates in a coastal pelagic food web. Mar Ecol Prog Ser 73:253-261

Hanslik M (1987) Nahrungsaufnahme und Nahrungsverwertung beim Meeresleuchttierchen Noctiluca miliaris. $\mathrm{PhD}$ thesis, University of Bonn (in German)

Huang C, Qi Y (1997) The abundance cycle and influence factors on red tide phenomena of Noctiluca scintillans (Dinophyceae) in Dapeng Bay, the South China Sea. J Plankton Res 19(3):303-318

Humphrey GF (1963) Seasonal variation in plankton pigments in waters off Sydney. Aust. J Mar Freshw Res 14: $24-36$

Jeffrey SW, Carpenter SM (1974) Seasonal succession of phytoplankton at a coastal station off Sydney. Aust J Mar Freshw Res 25:361-369

Lee R, Ajani P, Pritchard T, Black K (2001) Resolving climatic variance in the context of retrospective phytoplankton pattern investigations off the east coast of Australia. J Coast Res 34:74-86

Le Fevre J, Grall JR (1970) On the relationships of Noctiluca swarming off the western coast of Brittany with hydrological features and plankton characteristics of the environment. J Exp Mar Biol Ecol 4:287-306

Montani S, Pithakpol S, Tada K (1998) Nutrient regeneration in coastal seas by Noctiluca scintillans, a red tide-causing dinoflagellate. J Mar Biotechnol 6(4):224-228

Murray S, Suthers IM (1999) Population ecology of Noctiluca scintillans Macartney, a red-tide-forming dinoflagellate. Mar Freshw Res 50:243-252

Nakamura Y, Suzuki S, Hiromi J (1995) Population dynamics of heterotrophic dinoflagellates during a Gymnodinium mikimotoi red tide in the Seto Inland Sea. Mar Ecol Prog Ser 125:269-277

Naqvi SWA, George MD, Narvekar PV, Jayakumar DA and 
9 others (1998) Severe fish mortality associated with 'red tide' observed in the sea off Cochin. Curr Sci 75(6): 543-544

Painting SJ, Lucas IM, Peterson WT, Brown PC, Hutchings L, Mitchell-Innes BA (1993) Dynamics of bacterioplankton, phytoplankton and mesoplankton communities during the development of an upwelling plume in the southern Benguela. Mar Ecol Prog Ser 100:35-53

Pritchard T, Lee R (2001) How do ocean outfalls affect nutrient patterns in coastal waters of New South Wales, Australia? Aust J Coast Res 34:87-95

Rau GH (1982) The relationship between the trophic level and stable isotopes of carbon and nitrogen. In: Bascom W (ed) Coastal water research project biennial report for the years 1981-1982. Calif Water Res Proj, Long Beach, p 143-243

Rochford DJ (1975) Nutrient enrichment of east Australian coastal waters. II. Laurieton upwelling. Aust J Mar Freshw Res 26:233-243

Rochford DJ (1984) Nitrates in eastern Australian coastal waters. Aust J Mar Freshw Res 35:385-397

Sato MS, Suzuki M, Hayashi H (1998) The density of a homogenous population of cells controls resetting of the program for swarmer formation in the unicellular marine microorganism Noctiluca scintillans. Exp Cell Res 245: 290-293

Editorial responsibility: Otto Kinne (Editor), Oldendorf/Luhe, Germany
Schaumann K, Gerdes D, Hesse KJ (1988) Hydrographic and biological characteristics of a Noctiluca scintillans red tide in the German Bight, 1984. Meeresforschung 32:77-91

Smayda TJ (1997) What is a bloom? A commentary. Limnol Oceanogr 42(5):1132-1136

Takayama H (1984) Red tide organisms occurring in coastal waters of Hiroshima prefecture. II. Noctiluca scintillans (Macartney). Bull Hiroshima Fish Res Lab 14:25-29

Tranter DJ, Carpenter DJ, Leech GS (1986) The coastal enrichment effect of the East Australian Current eddy field. Deep-Sea Res 33:1705-1728

Uhlig G, Sahling G (1990) Long-term studies on Noctiluca scintillans in the German Bight population dynamics and red tide phenomena 1968-1988. Neth J Sea Res 25(1/2): 101-112

Uhlig G, Sahling G (1995) Noctiluca scintillans: Zeitliche Verteilung bei Helgoland und räumliche Verbreitung in der Deutschen Bucht (Langzeitreihen 1970-1993). Ber Biol Anst Helgol 9:1-127

Venrick EL (1993) Phytoplankton seasonality in the central North Pacific: the endless summer reconsidered. Limnol Oceanogr 38(6):1135-1149

Wada E, Terazaki M, Kabaya Y, Nemoto T (1987) ${ }^{15} \mathrm{~N}$ and ${ }^{13} \mathrm{C}$ abundances in the Antarctic Ocean with emphasis on the biogeochemical structure of the food web. Deep-Sea Res 34:829-841

Submitted: September 25, 2001; Accepted: January 31, 2002 Proofs received from author(s): May 27, 2002 